AKRUAL 1 (1) (2009): 28-44 $e$-ISSN: 2502-6380

\title{
AKRUAL
}

Jurnal Akuntansi

http://fe.unesa.ac.id/ojs/index.php/akrl

\section{PENGARUH PENERAPAN MEKANISME GOOD CORPORATE GOVERNANCE TERHADAP PRAKTIK MANAJEMEN LABA PADA PERUSAHAAN MANUFAKTUR YANG TERDAFTAR DI BURSA EFEK INDONESIA}

\author{
Elfrida Ambarita \\ Universitas Negeri Surabaya \\ E-mail: elfrida@yahoo.com \\ Dian Anita Nuswantara \\ Universitas Negeri Surabaya \\ E-mail: dianuswantoro@yahoo.com \\ Artikel diterima: 3 Agustus 2010 \\ Revisi terahir: 26 September 2010
}

\begin{abstract}
The conflict of interest between agent and principal, asymmetrical information and accounting method selection are able to be used by the manager to do earning management practices. However, it could be reduced by practicing the good corporate governance mechanism which can adjust agent and principal's interest.

The objective of this study is to test the effect of good corporate governance mechanism, as reflected by institutional ownership, managerial ownership, presence of independent board and audit committee existence on the earnings management practice. Using sample from 62 companies in the manufacturing sector at the Jakarta Stock Exchange, which publish financial statement from 2005-2006.

This study shows that good corporate governance mechanism insignificantly influence earnings management practice simultaneously. We can infer that mechanism haven't succeeded to minimize the earnings management practices.
\end{abstract}

Keywords: conflict of interest, asymmetric information, earnings management, good corporate governance

\section{PENDAHULUAN}

Dalam teori agensi, hubungan agensi muncul ketika satu orang atau lebih pemilik memperkerjakan agent untuk memberikan suatu jasa dan mendelegasikan wewenang kepada manajer (Jensen dan Meckling, 1976). Dalam hubungan agensi tersebut dapat terjadi konflik kepentingan antara agent (manajer) dan principal (pemilik), karena kedua pihak memiliki kepentingan yang berbeda. Sebagai manajer 
secara moral bertanggung jawab untuk mengoptimalkan keuntungan para pemilik, namun di sisi lain manajer mempunyai kepentingan memaksimumkan kesejahteraan mereka sehingga manajer tidak selalu bertindak demi kepentingan terbaik.

Manajer sabagai pengelola perusahaan lebih banyak mengetahui informasi tentang kondisi perusahaan daripada pemilik. Adanya informasi asimetris antarmanajer dan pemilik dapat memberikan kesempatan kepada manajer untuk bertindak oportunis dengan cara mengelola besarnya laba sesuai keinginan manajemen atau dikenal dengan manajemen laba (Richardson, 1998) dan Rachmawati (2006).

Laporan keuangan yang disusun berdasarkan akuntansi akrual mengharuskan pencatatan pendapatan dan beban berdasarkan saat terjadinya hak dan kewajiban, bukan saat penerimaan dan pengeluaran kas (Achmad, 2007). Dalam penerapan akuntansi akrual, prinsip akuntansi yang diterima umum memberikan fleksibilitas dengan memberikan keleluasaan kepada manajer untuk memilih kebijakan akuntansi dalam pelaporan laba. Namun fleksibilitas prinsip akuntansi tersebut menimbulkan peluang bagi manajer untuk melakukan manajemen laba.

Manajemen laba yang timbul akibat adanya konflik kepentingan, informasi asimetris, dan fleksibilitas dalam memilih kebijakan akuntansi dalam pelaporan keuangan dapat diminimumkan dengan cara menerapkan mekanisme good corporate governance yang tercermin melalui kepemilikan institusional, kepemilikan manajerial, komisaris independen, dan keberadaan komite audit. Hal tersebut dikarenakan dengan mekanisme good corporate governance diharapkan dapat menyelaraskan kepentingan manajer dengan pemilik (Midiastuty, 2003).

Mekanisme good corporate governance dicerminkan dari adanya kepemilikan institusional, kepemilikan manajerial, ukuran dewan komisaris independen, dan komite audit ditengarai mampu menghambat aktivitas manajemen laba. Oleh sebab itu di Indonesia telah ditetapkan peraturan untuk menerapkan good corporate governance demi terciptanya kinerja perusahaan yang bersih dan terlindunginya kepentingan pemilik. Bapepam mengharuskan perusahaan tercatat menerapkan good corporate governance melalui surat edaran dengan nomor SE-03/PM/2000.

Penelitian-penelitian tentang mekanisme good corporate governance terhadap manajemen laba telah dilakukan di dalam negeri maupun di luar negeri. Namun mekanisme good corporate governance terhadap manajemen laba tetap menarik untuk diteliti mengingat tidak konsistennya hasil-hasil penelitian tersebut. Chtourou (2001) menemukan bahwa earnings management secara signifikan berhubungan dengan beberapa praktik governance oleh dewan komisaris dan komite audit. Midiastuty (2003) menemukan bahwa kepemilikan institusional dan kepemilikan manajerial berpengaruh negatif terhadap manajemen laba. Ujiyantho (2007), Darmawati (2003) menemukan bahwa kepemilikan institusional tidak berpengaruh terhadap manajemen laba. Veronica (2005) menemukan bahwa kepemilikan institusional, proporsi komisaris independen, dan keberadaan komite audit tidak berpengaruh terhadap manajemen laba. Gabrielsen (1997) menemukan bahwa kepemilikan manajerial tidak berpengaruh terhadap manajemen laba. 
Berdasarkan uraian di atas, maka pertanyaan penelitian ini adalah: apakah penerapan mekanisme good corporate governance, dalam hal ini kepemilikan institusional, kepemilikan manajerial, proporsi dewan komisaris independen, dan keberadaan komite audit berpengaruh terhadap manajemen laba? Tujuan dari penelitian ini adalah untuk mengetahui apakah mekanisme good corporate governance berpengaruh terhadap manajemen laba. Hasil penelitian ini diharapkan dapat memberikan kontribusi kepada pihak-pihak yang berkepentingan, dalam hal ini investor, Bapepam, dan akademisi mengenai mekanisme good corporate governance dan praktik manajemen laba yang dilakukan perusahaan.

\section{KAJIAN PUSTAKA DAN PENGEMBANGAN HIPOTESIS Teori Agensi dan Informasi Asimetris}

Dalam teori agensi, hubungan agensi muncul ketika satu orang atau lebih (principal) mempekerjakan orang lain (agent) untuk memberikan suatu jasa dan kemudian mendelegasikan wewenang pengambilan keputusan kepada agent tersebut (Jensen dan Meckling, 1976). Namun dalam praktiknya akan timbul masalah (agency problem), karena ada kesenjangan kepentingan antara para pemilik dengan manajer. Pemilik memiliki kepentingan agar dana yang telah diinves-tasikannya memberikan pendapatan (stock returns) yang maksimal. Sedangkan pihak manajemen memiliki kepentingan terhadap perolehan insentif atas pengelolaan dana pemilik perusahaan. Konflik kepentingan tersebut dapat memicu manajemen untuk meningkatkan penjualan atau laba untuk meningkatkan kompensasi atau insentif yang mereka terima. Namun peningkatan penjualan atau laba tidak selalu meningkatkan kesejahteraan pemegang saham karena manajer dapat memanipulasi angka-angka tersebut dengan menggunakan metode akuntansi (Hartono, 2001). Hal tersebut didukung oleh hasil penelitian Healy (1985) bahwa manajer melakukan manipulasi atas laba untuk meningkatkan kompensasi mereka. Pada pemilik sendiri ada dua kepentingan yang berbeda apabila kepemilikan dipegang oleh investor institusional dan investor individual. Penelitian yang dilakukan oleh Rajgofal (1999) menemukan bahwa investor institusional tidak berfokus pada laba sekarang dibandingkan investor individual. Hal tersebut mengindikasikan bahwa investor institusional lebih mementingkan returns jangka panjang.

Manajer sebagai pihak yang bertugas untuk mengelola perusahaan mempunyai lebih banyak informasi mengenai kapasitas diri, lingkungan kerja, dan perusahaan secara keseluruhan. Sedangkan pemilik tidak memiliki informasi yang cukup tentang kinerja manajer. Hal inilah yang mengakibatkan adanya ketidakseimbangan informasi antara pemilik dan manajer. Ketidakseimbangan informasi inilah yang disebut dengan informasi asimetris (Ujiyantho, 2007). Richardson (1998) dan Rachmawati (2006) menemukan bahwa adanya asimetri antara manajer dengan pemilik dapat memberikan kesempatan kepada manajer untuk melakukan manajemen laba. Dalam kondisi tersebut diperlukan suatu mekanisme pengendalian yang dapat menyejajarkan perbedaan kepentingan antara kedua belah pihak. Mekanisme good corporate 
governance memiliki kemampuan dalam kaitannya menghasilkan suatu laporan keuangan yang memiliki kandungan informasi laba (Boediono, 2005).

\section{Kepemilikan Institusional}

Kepemilikan saham oleh investor institusional dapat menjadi kendala bagi perilaku oportunis manajemen yang memanfaatkan manajemen laba untuk kepentingan pribadinya, yang mungkin mengakibatkan kepentingan pihak lain terabaikan (Midiastuty, 2003). Hal tersebut didukung oleh penelitian yang dilakukan oleh Rajgofal (1999) yang menemukan hubungan negatif antara kepemilikan institusional dengan praktik manajemen laba. Hasil penelitian tersebut mengindikasikan bahwa manajer mengakui bahwa investor institusional adalah informed investor di-bandingkan dengan investor individual, sehingga motivasi manajer untuk melakukan menajemen laba berkurang sebab investor institusional tidak mudah dibodohi. Melalui penelitian tersebut juga ditemukan bahwa jika kepemilikan institusional meningkat, harga saham cenderung untuk mencerminkan proporsi informasi future earnings yang lebih besar relatif terhadap current earnings. Hasil tersebut konsisten dengan anggapan bahwa investor institusional tidak berfokus pada laba sekarang dibandingkan investor individual. Dengan adanya kepemilikan saham oleh investor institusional maka proses monitoring akan berjalan lebih efektif sehingga dapat mengurangi tindakan manajer dalam hal manajemen laba yang dapat merugikan kepentingan pemilik (Bushee, 1998). Dengan demikan kepemilikan institusional merupakan mekanisme good corporate governance, karena fungsi monitoring yang diberikan oleh investor institusional dapat memastikan bahwa manajer akan bertindak yang terbaik bagi kepentingan pemilik.

Darmawati (2003), Veronica (2005), dan Ujiyantho (2007), menemukan bahwa kepemilikan institusional tidak berpengaruh terhadap manajemen laba. Hasil penelitian mereka sejalan dengan pandangan atau konsep yang mengatakan bahwa institusional adalah pemilik yang lebih memfokuskan pada current earnings (Porter, 1992 dalam Pranata dan Mas'ud, 2003). Akibatnya manajer merasa terikat untuk memenuhi target laba dari para investor, sehingga mereka akan tetap cenderung terlibat dalam tindakan manipulasi laba. Manajer terpaksa untuk melakukan tindakan yang dapat meningkatkan laba jangka pendek, misalnya dengan melakukan manipulasi laba.

Namun beberapa penelitian yang lain menunjukkan bahwa kepemilikan institusional memiliki kemampuan untuk memengaruhi tindakan manajemen laba. Penelitian-penelitian tersebut telah dilakukan oleh Cornett (2006) yang menyatakan bahwa kepemilikan institusional yang besar mempunyai kesempatan, pengetahuan dan kemampuan untuk memonitor serta memengaruhi manajer dalam membuat keputusan. Pengawasan perusahaan yang dilakukan oleh investor institusional dapat mendorong manajer untuk lebih fokus pada kinerja perusahaan dan mengurangi kesempatan manajer untuk mengutamakan kepentingan pribadinya. Begitu pula penelitian yang dilakukan oleh Midiastuty (2003), dan Suranta (2005) mereka menemukan bahwa kepemilikan institusional mempunyai pengaruh yang negatif 
signifikan terhadap manajemen laba dikarenakan investor institusional lebih berpengalaman dibandingkan dengan investor individual. Dari beberapa penelitian di atas maka dapat disimpulkan bahwa kepemilikan institusional mempunyai pengaruh terhadap praktik manajemen laba karena dengan adanya kepemilikan institusional terdapat kemampuan untuk mengendalikan pihak manajemen melalui proses monitoring secara efektif sehingga dapat mengurangi tindakan manajer dalam melakukan manajemen laba.

\section{Kepemilikan Manajerial}

Kepemilikan saham perusahaan oleh manajer dapat menyejajarkan kepentingan pemilik atau pemegang saham dengan kepentingan manajer sehingga dapat mengurangi konflik kepentingan yang dapat mendorong manajer melakukan manipulasi (Jensen dan Meckling,1976). Oleh karena itu, dengan adanya kepemilikan manajerial, maka semakin rendah kecenderungan manajer melakukan manajemen laba.

Penelitian yang dilakukan oleh Gabrielsen (1997) dalam Ujiyantho (2007) menemukan hasil yang positif tetapi tidak signifikan antara kepemilikan manajerial dengan manajemen laba. Hal tersebut disebabkan karakteristik struktur kepemilikan yang berbeda di mana struktur kepemilikan yang diteliti oleh Gabrielsen cenderung lebih banyak dimiliki oleh institusi. Emiten yang dianalisis termasuk memiliki struktur kepemilikan yang terkonsentrasi pada suatu institusi yang biasanya memiliki saham yang cukup besar yang mencerminkan kekuasaan, sehingga mempunyai kemampuan untuk melakukan intervensi terhadap jalannya perusahaan dan mengatur proses penyusunan laporan keuangan. Akibatnya manajer terpaksa melakukan tindakan berupa manajemen laba demi untuk memenuhi keinginan pihak-pihak tertentu di antaranya pemilik.

Penelitian yang dilakukan oleh Midiastuty (2003) dan Ujiyantho (2007) mendukung hasil penelitian Jensen dan Meckling (1976). Mereka menemukan bahwa kepemilikan manajerial berpengaruh negatif terhadap manajemen laba. Ross (1999) dalam Siallagan (2006) menyatakan bahwa semakin besar kepemilikan manajemen dalam perusahaan maka manajemen akan cenderung untuk berusaha untuk meningkatkan kinerjanya untuk kepentingan pemegang saham dan untuk kepentingannya sendiri. Penelitian yang dilakukan oleh Warfield (1995) dalam Midiastuty (2003) juga menemukan hubungan yang negatif antara kepemilikan manajerial dengan manajemen laba.

\section{Proporsi Komisaris Independen}

Praktik good corporate governance mengharuskan adanya komisaris independen dalam perusahaan yang diharapkan mampu mendorong dan menciptakan iklim yang lebih independen, objektif, dan menempatkan kesetaraan sebagai prinsip utama dalam memerhatikan kepentingan pemegang saham minoritas dan stakeholder lainnya. Keberadaan komisaris independen dan kriterianya telah diatur melalui peraturan BEJ tanggal 1 Juli 2000. Dikemukakan bahwa perusahaan yang terdaftar di 
bursa harus mempunyai komisaris independen yang secara proporsional sama dengan jumlah saham yang dimiliki pemegang saham yang minoritas (bukan controlling shareholders).

Veronica (2005) yang meneliti pengaruh praktik corporate governance terhadap manajemen laba menemukan bahwa proporsi dewan komisaris independen tidak terbukti berpengaruh terhadap manajemen laba yang dilakukan oleh perusahaan. Hal tersebut dikarenakan pengangkatan komisaris independen hanya dilakukan untuk pemenuhan regulasi saja tetapi tidak dimaksudkan untuk menegakkan good corporate governance. Selain itu ketentuan minimum dewan komisaris independen sebesar $30 \%$ mungkin belum cukup tinggi untuk para komisaris independen dapat mendominasi kebijakan yang diambil oleh dewan komisaris. Suranta (2005) menemukan bahwa proporsi komisaris independen tidak mempunyai pengaruh terhadap manajemen laba. Hal tersebut mengindikasikan bahwa komisaris independen masih dipertanyakan tingkat independensinya.

Penelitian yang dilakukan oleh Wedari (2004) menemukan proporsi dewan komisaris independen mempunyai pengaruh negatif terhadap aktivitas manajemen laba. Hasil penelitian ini juga didukung oleh hasil penelitian Chtourou (2001), yang memberikan kesimpulan bahwa perusahaan yang memiliki proporsi anggota dewan komisaris yang berasal dari luar perusahaan atau outside director dapat memengaruhi tindakan manajemen laba. Sehingga, jika anggota dewan komisaris dari luar meningkatkan tindakan pengawasan, hal ini juga akan berhubungan de-ngan makin rendahnya aktivitas manajemen laba (Cornett, 2006). Dengan demikian dapat disimpulkan bahwa proporsi komisaris independen mempunyai pengaruh terhadap praktik manajemen laba karena dengan adanya komisaris independen maka tingkat pengawasan dapat semakin meningkat karena independensi yang dimiliki oleh dewan komisaris.

\section{Komite Audit}

Komite audit adalah suatu komite yang beranggotakan satu atau lebih dari anggota komisaris independen. Komite audit mempunyai tanggung jawab atas pengawasan (atas nama board of directors dan pemegang saham), untuk pelaporan luar perusahaan (mencakup laporan keuangan tahunan), pemonitoran risiko dan proses pengendalian baik fungsi audit internal maupun eksternal. Komite audit melakukan pengecekan independen atas manajemen dan sebagai penyokong untuk pemakai luar dalam meyakinkan bahwa laporan keuangan secara tepat menggambarkan aktivitas ekonomi perusahaan (Tunggal, 2002: 16).

Veronica (2005) menguji pengaruh keberadaan komite audit dalam perusahaan terhadap aktivitas manajemen laba. Dari penelitian tersebut ditemukan bahwa variabel keberadaan komite audit tidak berpengaruh terhadap manajemen laba perusahaan. Artinya keberadaan komite audit tidak mampu mengurangi manajemen laba yang terjadi di perusahaan. Hal tersebut dikarenakan pengangkatan komite audit oleh perusahaan hanya untuk pemenuhan regulasi saja tetapi tidak dimaksudkan untuk menegakkan good corporate governance. Selain itu jika kompetensi dan 
independensi komite audit tidak terpenuhi maka praktik manajemen laba tidak dapat dihindarkan (Cho, 2004 dalam Suranta, 2005).

Bachtiar (2004) menemukan bahwa komite audit memiliki hubungan yang signifikan terhadap aktivitas manajemen laba perusahaan manufaktur di Indonesia khususnya untuk periode 2001-2002, artinya kehadiran komite audit secara efektif menghalangi peningkatan manajemen laba di perusahaan tersebut. Penelitian yang dilakukan oleh Wedari (2004) menemukan bahwa manajemen laba pada perusahaan yang tidak mempunyai komite audit signifikan lebih tinggi daripada perusahaan yang tidak mempunyai komite audit. Hasil penelitian-penelitian terse-but juga didukung oleh penemuan yang dilakukan oleh Suranta (2005) dan Klein (2000), memberikan bukti secara empiris bahwa perusahaan yang membentuk komite audit independen melaporkan laba dengan kandungan akrual diskresioner yang lebih kecil dibandingkan dengan perusahaan yang tidak membentuk komite audit independen. Melalui beberapa hasil penelitian tersebut maka dapat disimpulkan bahwa keberadaan komite audit dapat mengurangi perilaku manajemen laba karena komite audit berperan sebagai salah satu mekanisme good corporate governance dalam membatasi praktik manajemen laba melalui fungsi pengawasan yang dilakukan.

\section{Pengembangan Hipotesis}

Berdasarkan beberapa penelitian yang telah diuraikan di atas maka hipotesis yang diajukan dalan penelitian ini adalah:

Ha: Mekanisme good corporate governance yang terdiri dari kepemilikan institusional, kepemilikan manajerial, komisaris independen, dan keberadaan komite audit mempunyai pengaruh terhadap manajemen laba.

\section{METODE PENELITIAN}

\section{Sampel Penelitian}

Perusahaan manufaktur yang menjadi sampel dalam penelitian tidak boleh mengalami penghentian operasi selama tahun penelitian yaitu 2005-2006 untuk menekan kemungkinan confounding effect. Di samping itu, sampel harus memiliki data kepemilikan institusional, kepemilikan manajerial, komisaris independen, dan ko-mite audit untuk menghindari missing data pada saat menjalankan program SPSS.

\section{Sumber Data}

Data yang digunakan dalam penelitian ini berupa data sekunder yang diambil dari laporan keuangan tahunan perusahaan untuk menghitung besarnya discretionary accruals sebagai proksi manajemen laba. Demikian pula data kepemilikan institusional, kepemilikan manajerial, komisaris independen, dan keberadaan komite audit, semua data tersebut diperoleh dari Indonesian Capital Market Directory (ICMD), dan www.jsx.co.id. 


\section{Definisi Operasional Variabel Penelitian}

1. Manajemen laba diproksikan dengan discretionary accruals menggunakan model modifikasi Jones. Model ini dianggap lebih baik di antara model yang lain untuk mengukur manajemen laba karena model ini memisahkan antara nondiscretionary accrual dengan discretionary accruals (Dechow, 1995). Nondiscretionary accruals merupakan komponen akrual yang diperoleh secara alamiah dari dasar pencatatan akrual dengan mengikuti standar akuntansi yang diterima secara umum, misalkan metode depresiasi dan penentuan persediaan yang dipilih harus mengikuti metode yang diakui dalam prinsip akuntansi. Discretionary accruals merupakan komponen akrual hasil rekayasa manajerial dengan memanfaatkan kebebasan dan keleluasaan dalam estimasi standar akuntansi (Sulistyantyo, 2008). Langkah awal untuk mengidentifikasi manajemen laba adalah dengan mengeluarkan komponen kas dari model akuntansi untuk menghitung dan menentukan besarnya komponen akrual yang diperoleh perusahaan selama satu periode tertentu, sehingga laba harus dikurangi dengan arus kas yang diperoleh dari operasi perusahaan selama periode yang bersangkutan:

$\mathrm{TAC}=\mathrm{Nit}-\mathrm{CFO}$ it.

$\mathrm{TAC}=$ NDAit + Dait.

Nilai total accrual (TA) yang diestimasi dengan persamaan regresi OLS sebagai berikut:

TAit/Ait-1 $=\beta_{1}\left(1 / A_{i t-1}\right)+\beta_{2}\left(\Delta R_{e v t} / A_{i t-1}-\Delta R_{e c t} A_{i t-1}\right)+\beta_{3}\left(\mathrm{PPE}_{t} / A_{i t}\right)$

Dengan menggunakan koefisien regresi diatas nilai non discretionary accruals (NDA) dapat dihitung dengan rumus:

$N A_{i t}=\beta_{1}\left(1 / A_{i t-1}\right)+\beta_{2}\left(\Delta \operatorname{Revt}_{t} / A_{i t-1}-\Delta R_{e c t} / A_{i t-1}\right)+\beta_{3}\left(P_{P E} / A_{i t-1}\right)$

Selanjutnya discretionary accrual (DA) dapat dihitung sebagai berikut:

DA $i$ = TAit $/$ Ait-1 - NDAit.

Keterangan:

$\mathrm{DA}_{\mathrm{it}}=$ Discretionary Accruals perusahaan i pada periode ke $\mathrm{t}$

NDA ${ }_{i t}=$ Non Discretionary Accruals perusahaan i pada periode ke $\mathrm{t}$

TA $\mathrm{it}=$ Total akrual perusahaan i pada periode ke $\mathrm{t}$

$\mathrm{N}_{\mathrm{it}}=$ Laba bersih perusahaan i pada periode ke-t

$\mathrm{CFO}_{\mathrm{it}}=$ Aliran kas dari aktivitas operasi perusahaan i pada periode ke $\mathrm{t}$

Ait-1 $=$ Total aktiva perusahaan i pada periode ke $\mathrm{t}-1$

$\Delta \mathrm{Revt}=$ Perubahan pendapatan perusahaan i pada periode ke $\mathrm{t}$

$\mathrm{PPE}_{\mathrm{t}}=$ Aktiva tetap perusahaan pada periode ke $\mathrm{t}$

$\Delta \mathrm{Rec}_{\mathrm{t}}=$ Perubahan piutang perusahaan i pada periode ke $\mathrm{t}$

$\mathrm{e}=$ error 
2. Kepemilikan institusional merupakan jumlah dari persentase saham yang dimiliki oleh investor institusional yang diambil dari catatan atas laporan keuangan.

3. Kepemilikan manajerial yaitu persentase saham yang dimiliki oleh manajemen yang secara aktif ikut dalam pengambilan keputusan perusahaan (direksi dan komisaris) yang diambil dari catatan atas laporan keuangan.

4. Komisaris independen diambil dari proporsi komisaris independen merupakan perbandingan jumlah komisaris independen yang dimiliki suatu perusahaan terhadap jumlah seluruh anggota dewan komisaris yang dinyatakan dalam persentase yang diambil dari catatan atas laporan keuangan.

5. Komite audit merupakan variabel dummy, bila perusahaan sampel memiliki komite audit maka dinilai 1 dan jika sebaliknya dinilai 0 . Keterangan atas keberadaan komite audit tersebut didapat dari catatan atas laporan keuangan atau pada annual report perusahaan.

\section{Teknik Analisis Data}

Teknik analisis data yang digunakan dalam penelitian ini adalah uji statistik untuk mengetahui adanya pengaruh mekanisme good corporate governance yang dicerminkan melalui kepemilikan institusional, kepemilikan manajerial, proporsi komisaris independen, dan keberadaan komite audit terhadap manajemen laba. Untuk menguji hipotesis digunakan alat regresi linier berganda.

Berikut ini adalah model persamaan regresi linier yang dipergunakan:

$$
Y=a+b_{1} X_{1}+b_{2} X_{2}+b_{3} X_{3}+b_{4} X_{4}+e
$$

$$
\begin{aligned}
& \text { Keterangan: } \\
& Y=\text { manejemen laba } \\
& X_{1}=\text { kepemilikan institusional } \\
& X_{2}=\text { kepemilikan manajerial } \\
& X_{3}=\text { proporsi komisaris independen } \\
& X_{4}=\text { keberadaan komite audit } \\
& e \quad=\text { error term }
\end{aligned}
$$

\section{HASIL DAN PEMBAHASAN}

\section{Hasil Uji Asumsi Klasik}

Berdasarkan hasil pengujian asumsi klasik untuk model regresi yang digunakan dapat diperoleh kesimpulan semua asumsi telah terpenuhi berdasarkan hasil berikut:

1. Uji normalitas dengan menggunakan histogram dan grafik normal probability plot. Gambar histogram menunjukkan suatu pola yang menggambarkan pola distribusi yang tidak menceng ke kiri maupun ke kanan. Sedangkan dari hasil grafik normal probability plot menunjukkan penyebaran data yang berada di sekitar garis diagonal dan mengikuti arah garis diagonal. Dari kedua gambar tersebut dapat disimpulkan bahwa data terdistribusi normal. 
2. Nilai Variance Inflation Factor untuk masing-masing variabel independen dalam persamaan pertama memiliki nilai kurang dari 10 dan nilai tolerance lebih besar dari 0,10 sehingga dapat disimpulkan bahwa tidak ada multikolinieritas antar variabel independen.

3. Berdasarkan hasil pengujian terhadap gejala autokorelasi diperoleh nilai DWhitung sebesar 1,771. Karena dihasilkan nilai dU<DW-hitung $<4$-dU maka dapat disimpulkan tidak terjadi autokorelasi positif ataupun negatif pada model regresi yang digunakan.

4. Berdasarkan hasil pengujian terhadap gejala heterokedastisitas dengan menggunakan uji glejser nilai signifikansi semua variabel berada di atas 0,05 maka dapat disimpulkan tidak terjadi gejala heterokedastisitas pada model regresi yang digunakan.

\section{Pengujian Hipotesis dan Pembahasan}

Berdasarkan tabel hasil uji $F$ dapat dilihat bahwa tingkat signifikansi adalah sebesar 0,772 lebih besar dibadingkan dengan 0,05 maka $\mathrm{H}_{0}$ diterima dan $\mathrm{H}_{\mathrm{a}}$ ditolak. Sehingga dapat disimpulkan bahwa variabel independen yang terdiri dari kepemilikan institusional, kepemilikan manajerial, proporsi komisaris independen, dan komite audit secara bersama-sama tidak mempunyai pengaruh terhadap praktik manajemen laba perusahaan manufaktur yang terdaftar di BEI. Uji $t$ tidak dilakukan karena uji $F$ menunjukkan hasil yang tidak signifikan.

Berdasarkan hasil penelitian, rata-rata perusahaan sampel memiliki persentase kepemilikan institusional sebesar $68,42 \%$. Setelah dilakukan pengujian hipotesis maka didapatkan bahwa kepemilikan institusional tidak berpengaruh terhadap praktik manajemen laba yang dilakukan oleh perusahaan. Hasil penelitian ini tidak mendukung penelitian yang dilakukan Jensen dan Meckling (1976), dan Pranata dan Mas'ud (2003) yang menemukan adanya pengaruh negatif signifikan. Namun hasil penelitian ini mendukung hasil penelitian yang dilakukan oleh Darmawati (2003), Veronica (2005), dan Ujiyantho (2007). Hasil penelitian ini sejalan dengan pandangan atau konsep yang mengatakan bahwa kepemilikan institusional adalah pemilik yang lebih memfokuskan pada current earnings (Porter, 1992 dalam Pranata dan Mas'ud 2003). Akibatnya manajer terpaksa untuk melakukan tindakan yang dapat meningkatkan laba jangka pendek, misalnya dengan melakukan manipulasi laba. Pandangan yang sama juga dikemukakan oleh Cornett (2006) dalam Ujiyantho (2007) yang menyatakan bahwa kepemilikan institusional akan membuat manajer merasa terikat untuk memenuhi target laba dari para investor, sehingga mereka akan tetap cenderung terlibat dalam tindakan manipulasi laba.

Variabel kepemilikan manajerial tidak berpengaruh terhadap manajemen laba. Hal ini mungkin disebabkan jumlah kepemilikan manajerial untuk perusahaan yang terdaftar di BEI relatif lebih sedikit dengan kepemilikan institusional. Hasil penelitian ini tidak mendukung penelitian yang dilakukan oleh Midiastuty (2003) dan Ujiyantho (2007). Namun hasil penelitian ini mendukung hasil penelitian yang dilakukan oleh Gabrielsen (1997) dalam Ujiyantho (2007) menemukan hasil yang positif tetapi tidak 
signifikan antara kepemilikan manajerial dengan manajemen laba. Dari hasil penelitian ini dapat disimpulkan bahwa pada praktiknya meskipun kompensasi yang diberikan kepada manajer melalui kepemilikan saham bukan berarti tidak mungkin terjadi manipulasi yang berupa manajemen laba, hal tersebut dikarenakan kepemilikan manajerial memiliki kepentingan tersendiri dengan praktik manajemen laba yang dilakukan oleh perusahaan dan kepentingan tersebut kemungkinan sejalan dengan kepentingan para manajer. Selain itu kepemilikan manajerial tidak berpengaruh terhadap praktik manajemen laba, dapat juga dikarenakan karakteristik manajer di Indonesia yang cenderung mengarah seperti tipe perilaku organisasi di Amerika, yaitu cenderung berpindah-pindah untuk mencari kesempatan, kemajuan, dan perubahan karir. Danandjaja (1985) dalam Rini (2002) dalam penelitiannya menemukan bahwa manajer Indonesia lebih mementingkan keuntungan jangka pendek dan cenderung tidak mempunyai ikatan yang kuat dengan perusahaan. Karena tidak ada ikatan lain kecuali sebagai wadah tempat ia memperoleh kesempatan kerja, jaminan, dan keamanan, maka para manajer akan cenderung untuk keluar dari perusahaannya begitu saja kalau hal-hal tersebut tidak dipenuhi sehingga walaupun seorang manajer diberikan proporsi saham maka hal tersebut tidak akan dapat berpengaruh untuk mengurangi tindakan manajemen laba karena manajer tidak merasa bahwa sebagai pemegang saham maka manajer sekaligus adalah pemilik perusahaan.

Hasil pengujian hipotesis menunjukkan bahwa proporsi komisaris independen tidak mempunyai pengaruh terhadap manajemen laba. Hasil penelitian ini tidak mendukung hasil penelitian yang dilakukan oleh Wedari (2004) dan Suranta (2005) yang menemukan hasil proporsi komisaris independen mempunyai pengaruh terhadap manajemen laba. Namun hasil penelitian ini mendukung hasil penelitian Veronica (2005) yang juga menemukan bahwa proporsi komisaris independen tidak mempunyai pengaruh terhadap manajemen laba. Hal tersebut mungkin dikarenakan bahwa pengangkatan komisaris independen oleh perusahaan hanya untuk pemenuhan regulasi saja, selain itu ketentuan minimum dewan komisaris independen sebesar $30 \%$ mungkin belum cukup tinggi untuk menyebabkan para komisaris independen tersebut dapat mendominasi kebijakan yang diambil oleh dewan komisaris dan mungkin dapat lebih efektif dalam menjalankan peran monitoring perusahaan. Kondisi ini didukung oleh survai Asian Development Bank bahwa kuatnya kendali pendiri perusahaan dan kepemilikan saham mayoritas menjadikan dewan komisaris tidak independen dan fungsi pengawasan yang seharusnya menjadi tanggung jawabnya menjadi tidak efektif. Ada kemungkinan penempatan atau penambahan anggota dewan dari luar perusahaan hanya sekadar memenuhi ketentuan formal, sementara pemegang saham mayoritas (pengendali/ founders) masih memegang peranan penting sehingga kinerja dewan tidak meningkat bahkan bisa menurun. Hal tersebut dapat juga terjadi karena kondisi pasar modal Indonesia yang memiliki ciri utama terkonsentrasi pada kelompok tertentu mengakibatkan pemegang saham mayoritas memiliki akses yang besar untuk memengaruhi keputusan manajerial (Surya, 2008: 57). 
Dalam penelitian variabel komite audit tidak memiliki pengaruh terhadap manajemen laba. Hasil penelitian ini mendukung hasil penelitian dari Veronica (2005) yang juga menemukan bahwa komite audit tidak mempunyai pengaruh terhadap manajemen laba. Hal tersebut menurut Veronica (2005), keberadaan komite audit oleh perusahaan mungkin hanya dilakukan untuk pemenuhan regulasi saja tetapi tidak dimaksudkan untuk menegakkan good corporate governance dalam perusahaan. Hal tersebut didukung oleh sebuah riset yang dilakukan oleh The Indonesian Institute for Corporate Governance terhadap 52 perusahaan publik, di mana sekitar $65 \%$ perusahaan publik menyatakan menerapkan corporate governance karena memang regulasi mengharuskannya (Surya, 2008: 61). Keberadaan komite audit di perusahaan publik tersebut sebagian besar hanya sekadar memenuhi tuntutan regulator (Bapepam \& BEJ).

\section{SIMPULAN \& SARAN \\ Simpulan}

Berdasarkan hasil pengujian hipotesis maka didapatkan bahwa mekanisme Good Corporate Governance yang tercermin dari kepemilikan institusional, kepemilikan manajerial, komisaris independen dan komite audit dalam penelitian ini tidak berpengaruh terhadap praktik manajemen laba.

Penelitian ini diharapkan dapat berguna bagi pengambil kebijakan dalam pengambilan kebijakan dari penerapan good corporate governance. Keberadaan komite audit dan komisaris independen di perusahaan publik sebagian besar hanya sekadar memenuhi tuntutan regulator (Bapepam dan BEJ). Hal tersebut dapat diketahui yang ditunjuk sebagai anggota komite audit dan komisaris independen di perusahaan publik banyak yang belum memenuhi kualitas dan kompetensi seperti yang diharapkan. Oleh karena itu pihak regulator, Bapepam dan BEJ perlu melakukan monitoring secara periodik eksistensi dan efektivitas komite audit dan komisaris independen di perusahaan publik. Bagi investor apabila manajemen laba bersifat oportunis maka semakin besar pengelolaan laba semakin tidak mencerminkan kinerja perusahaan yang sesungguhnya. Hal itu perlu menjadi per-hatian investor dalam melakukan keputusan investasi.

\section{Saran}

Untuk mengembangkan dan menyempurnakan penelitian mekanisme good corporate governance dan praktik manajemen laba, maka peneliti mengajukan beberapa saran yaitu:

1. Menggunakan sampel dari industri yang sama dan kategori industri lainnya, untuk menguji kembali mekanisme good corporate governance dan praktik manajemen laba. Dengan pengambilan sampel yang berasal dari berbagai ketegori industri diharapkan hasil analisis akan memiliki tingkat generalisasi yang lebih besar.

2. Penelitian selanjutnya menggunakan periode atau rentang waktu penelitian yang lebih panjang. Penggunaan periode yang lebih diharapkan pengukuran terhadap tren manajemen laba dan penerapan mekanisme good corporate governance oleh perusahaan bisa lebih akurat. 


\section{DAFTAR PUSTAKA}

Achmad, Komaruddin, dkk. 2007. Investigasi Motivasi dan Strategi Manajemen Laba pada Perusahaan Piblik di Indonesia. Simposium Nasional Akuntansi X. UnhasMakasar: 26-27 Juli 2007

Bachtiar, Yanivi dan Veronica, Sylvia. 2005. "Corporate Governance, Information Asymmetri and Earnings Management”. Jurnal Akuntansi dan Keuangan Indonesia.

Boediono, Gideon SB. Kualitas Laba: Studi Pengaruh Mekanisme Corporate Governance dan Dampak Manajemen Laba dengan Menggunakan Analisis Jalur. Simposium Nasional Akuntansi VIII. Solo: 15-16 September 2005.

Bushee, Brian. 1998. Institusional Investor, Long Term Invesment and Earnings Management. Working Paper. http://ssrn.com.

Chtourou, SM, J, Berdar, dan L, Corteau. 2001. "Corportae Governance and Earning Management". Working Paper. http://ssrn.com.

Cornett, Marcia, dkk. 2006. Corporate Governance, Earning Management, and True Financial Performance. Working Paper. http://ssrn.com.

Darmawati, Deni. 2003. "Corporate Governance dan Manajemen Laba: Suatu Studi Empiris". Jurnal Bisnis dan Akuntansi, Vol 5, No 1.

Jensen, Michael C, dan Meckling, William.1976. "Theory of the Firm: Managerial Behavior,Agency Costs and Ownership Structure". Journal of Financial Eonomics, Vol 3. No 4.

Hartono, Jogiyanto dan Ratnaningsih, Dewi. 2001. Conflict Of Interest Problem In The Management Controlled Firm. Jurnal Ekonomi dan Bisnis, Vol 16. No 1.

Healy, P.M. 1985. "The Effect of Bonus Schemes on Accounting Decisions". Journal of Accounting and Economics 7, pp. 85-107.

Klein. A. 2000. Audit Committe, Board Of Directors Characteristic, And Earnings Management. Working Paper. http://ssrn.com.

Midiastuty, Pratana dan M. Machfoedz. 2003. Analisis Hubungan Mekanisme Corporate Governannce dan Indikasi Manajemen Laba. Simposium Nasional Akuntansi VI. Surabaya: 16-17 Oktober 2003.

Rahmawati, dkk. 2006.Pengaruh Informasi asimetris terhadap Praktik Manajemen Laba pada perusahaan Perbankan Publik yang terdaftar di Bursa Efek Jakarta. Simposium Nasional Akuntansi IX. Padang: 23-26 Agustus 2006.

Rajgofal, dkk. 1999. Is Institusional Ownership Assoctiated with Earning Management and the Extent to which Stock Prices Reflect Future Earnings. http //ssrn.com.

Richardson, V. J. 1998. Information Asymmetry and Earnings Management: Some Evidence. http //.ssrn.com.

Rini, Endang sulistya. 2002. Manajemen Indonesia: Perpaduan Manajemen Barat dan Timur serta Budaya Tradisional. USU Digital Library

Sulistyanto, Sri. 2008. Manajemen Laba: Teori dan Model Empiris. Jakarta: Grasindo 
Suranta, Edy dan Midiastuty, Pratana Puspa. 2005. Pengaruh Good Corporate Governance Terhadap Praktik Manajemen Laba. Konferensi Nasional Akuntansi.

Surya, Indra dan Yustiavandana, Ivan. 2008. Penerapan Good Corporate Governance. Jakarta: Kencana Prenada Media Group.

Siallagan, Hamonangan, dan Machfoedz, Mas'ud. 2006. Mekanisme Corporate Governance, Kualitas Laba dan Nilai Perusahaan. Simposium Nasional Akuntansi IX. Padang: 23-26 Agustus 2006.

Ujiyantho, Arief dan Pramuka, Bambang Agus. 2007. Mekanisme Corporate Governance, Manajemen Laba dan Kinerja Keuangan. Simposium Nasional Akuntansi X. Unhas Makasar: 26-28 Juli 2007.

Veronica, Sylvia Dr dan Utama, Sidharta Dr. 2005. Pengaruh Struktur Kepemilikan, Ukuran Perusahaan, dan Praktik Corporate Governance ter-hadap Pengelolaan Laba (Earnings Management). Simposium Nasional Akuntansi VIII. Solo: 15 16 September 2005.

Wedari, Linda Kusumaning. 2004.Analisis Pengaruh Proporsi Dewan Komisaris dan Keberadaan Komite Audit terhadap Aktivitas Manajemen Laba. Makalah Simposium Nasional Akuntansi VII. Bali: 2-3 Desember 2004. 


\section{Uji Asumsi Klasik dan Uji Regresi}

Descriptive Statistics
\begin{tabular}{|l|r|r|r|}
\hline & \multicolumn{1}{|c|}{ Mean } & Std. Deviation & \multicolumn{1}{c|}{ N } \\
\hline DTAC & .0113632 & .13808710 & 124 \\
\%Kepemilikan & 68.4259 & 18.05603 & 124 \\
Institusional & & & \\
\%KepemilikanManajerial & 3.8798 & 6.31522 & 124 \\
\%KomIndependen & 38.22 & 10.426 & 124 \\
KomiteAudit & .90 & .297 & 124 \\
\hline
\end{tabular}

Model Summary ${ }^{b}$

\begin{tabular}{|c|c|c|c|c|c|c|c|c|c|c|}
\hline \multirow[b]{2}{*}{ Model } & \multirow[b]{2}{*}{$\mathrm{R}$} & \multirow[b]{2}{*}{ R Square } & \multirow[b]{2}{*}{$\begin{array}{l}\text { Adjusted } \\
\text { R Square }\end{array}$} & \multirow[b]{2}{*}{$\begin{array}{l}\text { Std. Error of } \\
\text { the Estimate }\end{array}$} & \multicolumn{5}{|c|}{ Change Statistics } & \multirow[b]{2}{*}{$\begin{array}{l}\text { Durbin- } \\
\text { Watson }\end{array}$} \\
\hline & & & & & $\begin{array}{l}\text { R Square } \\
\text { Change }\end{array}$ & F Change & $\mathrm{df1}$ & $\mathrm{df} 2$ & Sig. FChange & \\
\hline 1 & $.122^{\mathrm{a}}$ & .015 & -.018 & .13933800 & .015 & .450 & 4 & 119 & .772 & 1.771 \\
\hline
\end{tabular}

a. Predictors: (Constant), KomiteAudit, \%KomIndependen, \%KepemilikanManajerial , \%KepemilikanInstitusional

b. Dependent Variable: DTAC

\begin{tabular}{|c|c|c|c|c|c|c|c|c|c|c|c|c|c|}
\hline \multicolumn{14}{|c|}{ Coefficients $^{\mathrm{a}}$} \\
\hline \multirow[b]{2}{*}{ Model } & & \multicolumn{2}{|c|}{$\begin{array}{l}\text { Unstandardized } \\
\text { Coefficients }\end{array}$} & \multirow{2}{*}{$\begin{array}{c}\text { Standardized } \\
\text { Coefficients }\end{array}$} & \multirow[b]{2}{*}{ t } & \multirow[b]{2}{*}{ Sig. } & \multicolumn{2}{|c|}{$95 \%$ Confidence Interval for B } & \multicolumn{3}{|c|}{ Correlations } & \multicolumn{2}{|c|}{ Collinearty Statistics } \\
\hline & & $\mathrm{B}$ & Std. Error & & & & Lower Bound & Upper Bound & Zero-order & Partial & Part & Tolerance & VIF \\
\hline 1 & (Constant) & .059 & .087 & & .676 & .500 & -.231 & .113 & & & & & \\
\hline & $\begin{array}{l}\text { \%Kepemilikan } \\
\text { Institusional }\end{array}$ & .001 & .001 & 127 & 1.206 & .230 & .001 & .003 & .099 & .110 & .110 & .742 & 1.348 \\
\hline & \%KepemilikanManajerial & .001 & .002 & .064 & .608 & .544 & -.003 & .006 & .001 & .056 & .055 & .747 & 1.339 \\
\hline & \%Komlndependen & .000 & .001 & .026 & .289 & .773 & .002 & .003 & .028 & .026 & .026 & .999 & 1.001 \\
\hline & KomiteAudit & .017 & .043 & -.036 & .398 & .691 & .101 & .067 & -.045 & -.036 & -.036 & .990 & 1.010 \\
\hline
\end{tabular}

a. Dependent Variable: DTAC 
Histogram

Dependent Variable: DTAC

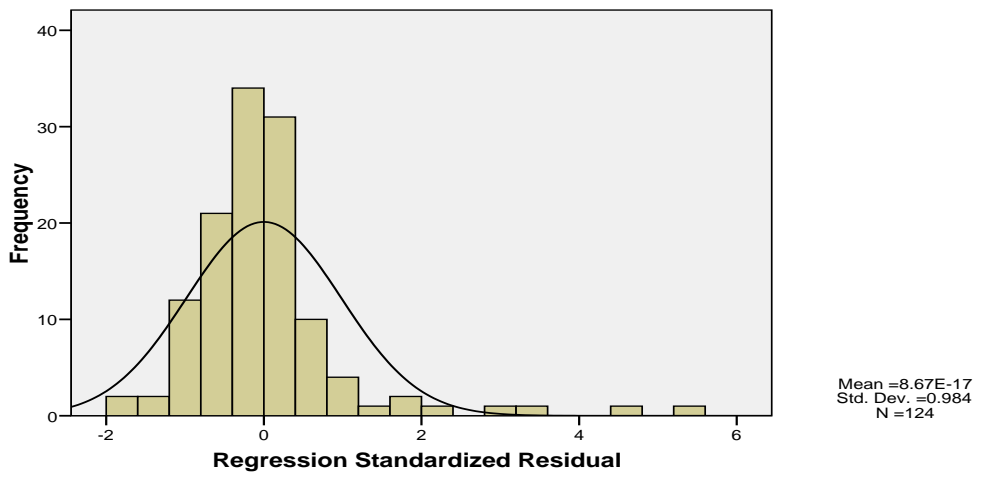

Normal P-P Plot of Regression Standardized Residual

Dependent Variable: DTAC

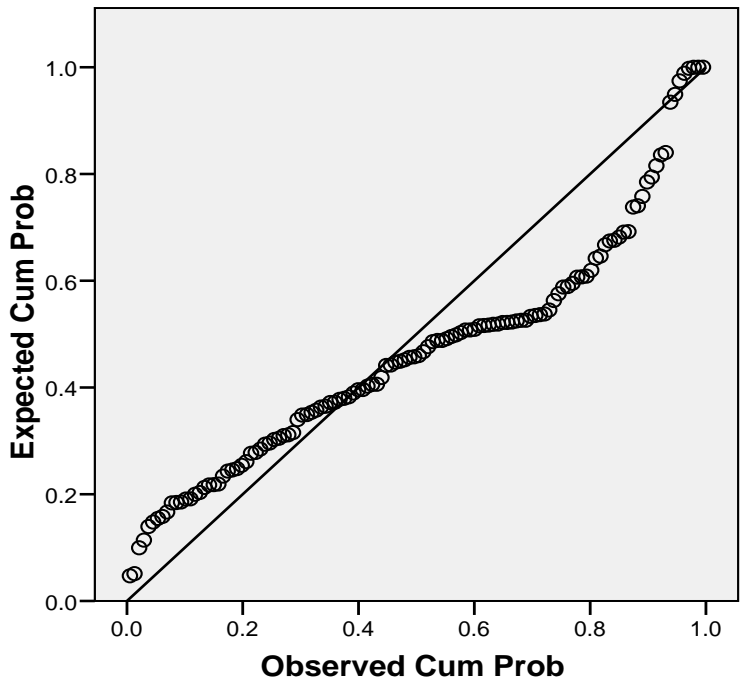




\section{Uji Heterokedastisitas}

\begin{tabular}{|c|c|c|c|c|c|c|c|c|c|c|c|c|c|}
\hline \multirow[b]{2}{*}{ Model } & & \multicolumn{2}{|c|}{$\begin{array}{l}\text { Unstandardized } \\
\text { Coefficients }\end{array}$} & \multirow{2}{*}{$\begin{array}{c}\begin{array}{c}\text { Standardized } \\
\text { Coefficients }\end{array} \\
\text { Beta }\end{array}$} & \multirow[b]{2}{*}{ t } & \multirow[b]{2}{*}{ Sig. } & \multicolumn{2}{|c|}{$95 \%$ Confidence Interval for B } & \multicolumn{3}{|c|}{ Correlations } & \multicolumn{2}{|c|}{ Collinearity Statistics } \\
\hline & & B & Std. Error & & & & Lower Bound & Upper Bound & Zero-order & Partial & Part & Tolerance & VF \\
\hline \multirow[t]{5}{*}{1} & (Constant) & .091 & .068 & & 1.346 & .181 & -043 & .226 & & & & & \\
\hline & $\begin{array}{l}\text { \%Kepemilikan } \\
\text { Institusional }\end{array}$ & .001 & .001 & .124 & 1.188 & .237 & $=001$ & .002 & 139 & .108 & .107 & .742 & 1.348 \\
\hline & \%KepemillkanManajerial & .000 & .002 & -009 & .087 & .931 & .004 & .003 & $: 077$ & -.008 & -008 & .747 & 1.339 \\
\hline & \%Komlndependen & -001 & .001 & .057 & .635 & .527 & .002 & .001 & .059 & .058 & .057 & .999 & 1.001 \\
\hline & KomiteAudit & -.041 & .033 & -110 & -1.221 & .225 & .106 & .025 & .124 & .111 & .110 & .990 & 1.010 \\
\hline
\end{tabular}

a. Dependent Variable: absres 